\title{
EBOLA, MEASLES, COVID-19 AND INSURGENCY - THE MULTIPLE FRONTS OF WAR IN THE DEMOCRATIC REPUBLIC OF THE CONGO
}

\section{EBOLA, ODRA, COVID-19 I REBELIA - WIELE FRONTÓW WOJNY W DEMOKRATYCZNEJ REPUBLICE KONGO}

\author{
Shibu Sasidharan ${ }^{1(\mathrm{~A}, \mathrm{~B}, \mathrm{C}, \mathrm{D}, \mathrm{E}, \mathrm{F})}$, Rashmi Datta $^{2(\mathrm{~A}, \mathrm{D}, \mathrm{F})}$ \\ ${ }^{1}$ HOD, Department of Anesthesiology and Critical Care, Level III IFH, United Nations Organization Stabilization \\ Mission in the Democratic Republic of the Congo, Goma, the Democratic Republic of the Congo \\ ${ }^{2} \mathrm{MG}$ (Med), Delhi Area, New Delhi, India
}

Authors' contribution Wkład autorów:

A. Study design/planning zaplanowanie badań B. Data collection/entry zebranie danych

C. Data analysis/statistics dane - analiza i statystyki D. Data interpretation interpretacja danych E. Preparation of manuscript przygotowanie artykułu F. Literature analysis/search wyszukiwanie $i$ analiza literatury G. Funds collection zebranie funduszy
Tables: 0

Figures: 2

References: 13

Submitted: 2020 Jul 17

Accepted: 2020 Jul 27

\section{Dear Editor,}

North Kivu (Figure 1) is the epicentre of the Kivu Conflict where armed conflict between the military of the Democratic Republic of the Congo (Armed Forces of the Democratic Republic of the Congo - FARDC) and the Hutu Power group has resulted in violent armed clashes and inter-communal conflict [1]. With a 21,000-strong force, United Nations Organization Mission in the Democratic Republic of the Congo (MONUSCO) constitutes the largest peacekeeping force currently in operation. This area has about one million uprooted people and shares its borders with Uganda and Rwanda, with cross border movement for trade. The humanitarian crisis and deterioration of the security situation of this nature is expected to affect any response to the outbreak [2].

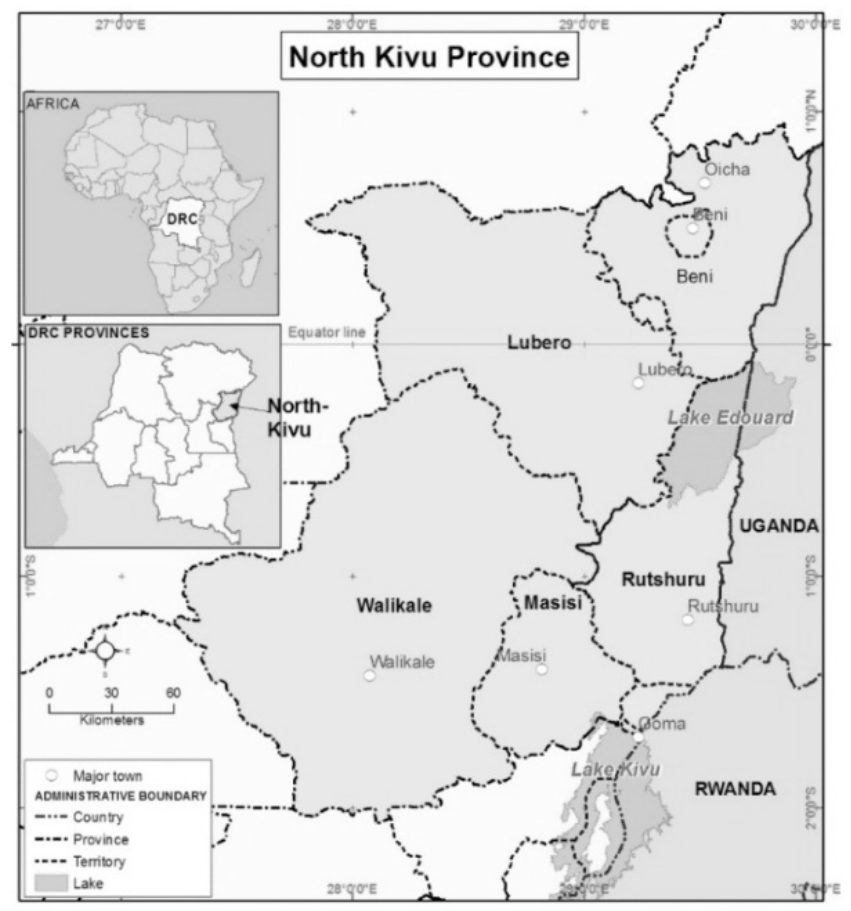

Figure 1. North Kivu [3]

Sasidharan S, Datta R. Ebola, measles, Covid-19 and insurgency - the multiple fronts of war in the Democratic Republic of the Congo. Health Prob Civil. 2020; 14(4): 243-246. https://doi.org/10.5114/hpc.2020.97779

Address for correspondence / Adres korespondencyjny: Shibu Sasidharan, HOD, Department of Anaesthesia and Critical Care, Level III IFH Hospital, MONUSCO Base, Goma, the Democratic Republic of the Congo, e-mail: shibusasi@gmail.com, phone: +917507111992, ORCID: Shibu Sasidharan https://orcid.org/0000-0003-2991-7595 Copyright: (C) Pope John Paul II State School of Higher Education in Biała Podlaska, Shibu Sasidharan, Rashmi Datta. This is an Open Access journal, all articles are distributed under the terms of the Creative Commons Attribution-NonCommercial-ShareAlike 4.0 International (CC BY-NC-SA 4.0) License (http://creativecommons.org/licenses/by-nc-sa/4.0/), allowing third parties to copy and redistribute the material in any medium or format and to remix, transform, and build upon the material, provided the original work is properly cited and states its license. 
WHO described this combination of violence and disease outbreaks as a "perfect storm", in their statement "A perfect storm of active conflict, limiting our ability to access civilians, distress by segments of the community, already traumatized by decades of conflict and of murder" [4]. That in addition to misinformation by the opposition party politicians and the attack on UN health workers makes medical aid challenging to deliver.

The Ebola Virus Disease (EVD) raged through Africa between 2014-2016, and went on to be the biggest International Public Health Concern of International Concern (PHEIC) of the decade (Figure 2). Fragile surveillance systems and weak public health infrastructure contributed to inability to contain this outbreak and it quickly spread, enveloping the neighbouring countries and wreaking havoc. The WHO lifted the PHEIC status on Africa's Ebola situation on Mar 29, 2016, but the impact this epidemic had on the world, and principally West Africa, is weighty. The 10th outbreak of Ebola virus disease in the Democratic Republic of the Congo (DRC) has been ongoing since August 2018. This is the largest-ever outbreak reported in the country and the world's second largest in history. It has been been declared a PHEIC on 17 Jul 2019 [5]. On 14 May 2020, the Ministry of Health began the 42-day countdown to the declaration of the end of that outbreak. Cases had dropped to zero by 17 Feb 2020 [6], but after 52 days without a case, surveillance and response teams on the ground confirmed three new cases of Ebola in Beni health zone in mid-April [7] raising concerns of an animal reservoir.

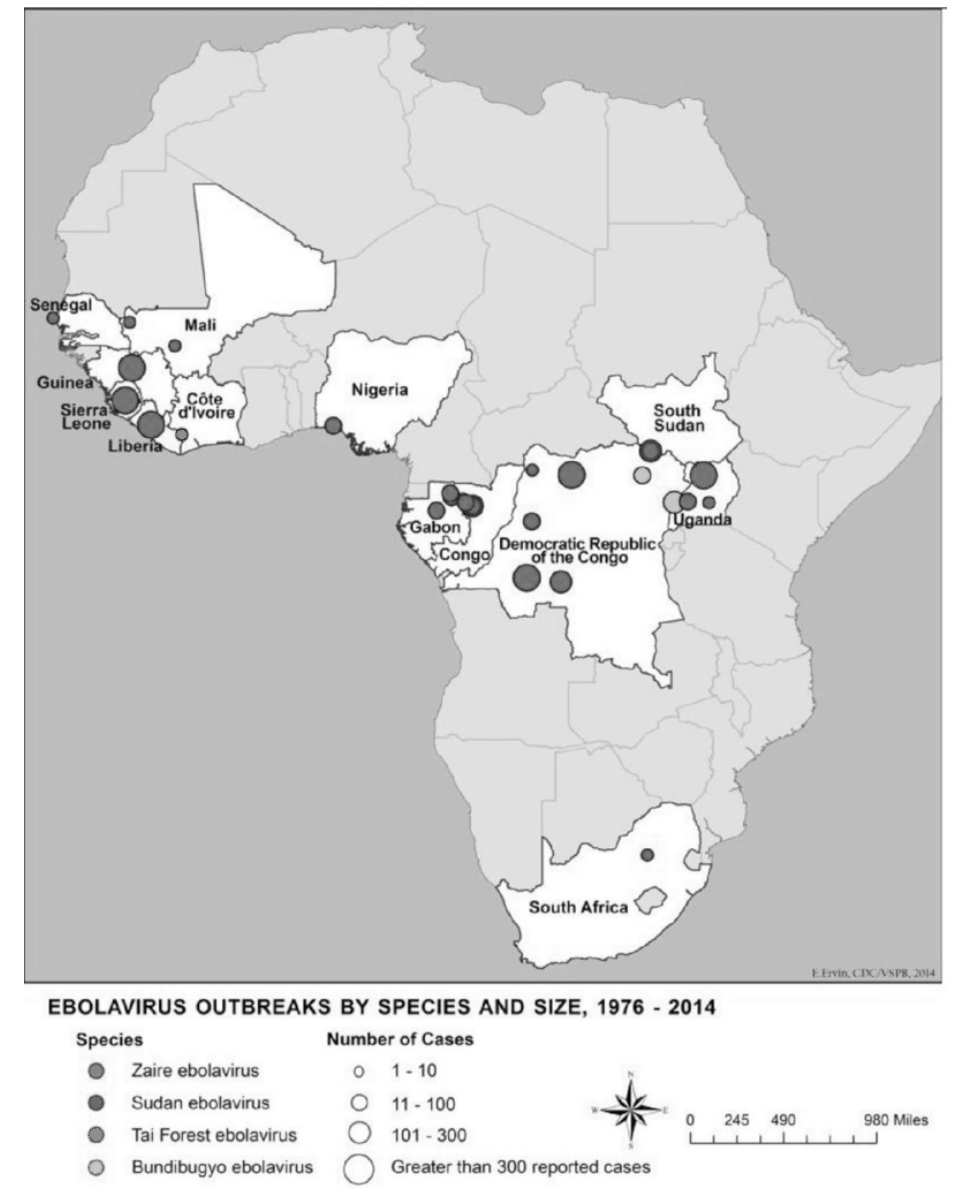

Figure 2. Ebola outbreak [8]

Healthcare workers (HCWs) caring for EVD patients are at the highest risk for contracting the disease. Compounding the overwhelming effects EVD had on the HCWs, there was concomitant setbacks in the treatment and control of major health issues like HIV, tuberculosis, measles, and malaria in these countries [9].

DRC's fight with EVD was just settling when WHO declared Covid-19 to be a PHEIC on Mar 12, 2020 [10]. DRC announced its first case on Mar 10, 2020 - a Congolese man who had travelled from France and transited through Kinshasa. The Ministry of Health and Social Affairs communiqués [11] reported 3763 cases (81 deaths, 512 recoveries, 7 cases transferred outside the country, 143 fresh cases in a day) and 2016 persons under observation as of Jun 62020 with a transmission classification status as per WHO being Community Transmission. Covid-19 
continues to spread faster here than in the neighbouring countries like Senegal, which, together with Mali and Nigeria, were the 4 countries which successfully tackled the 2014 Ebola outbreak in Africa [12]. Government authorities in DRC has placed various measures like systematic body temperature screening and public gathering and suspension of all flights and banning all air traffic since Mar 19 2020. Borders were closed and a state of emergency was declared on Mar 24. But despite these measures, the virus's continued progression throughout the country suggests that these measures were inadequate [5]. WHO has provided testing kits to the National Institute for Biomedical Research (INRB), Kinshasa and thirty-nine laboratories in the WHO African region now test for Covid-19.

Measles is a major concern in the DRC. Since 2019, 3,69,520 cases and 6779 deaths have been reported [13]. This has been named as the world's worst measles epidemic outbreak by the WHO [13]. The ongoing Congo EVD outbreak and civil unrest has had a negative and disastrous impact on routine child immunization in the DRC.

On analysis of the spatial events leading to rapid spread and increased severity of EVD in West Africa, with consequent high fatality rates, and extrapolating it with the pattern of the current pandemic of Covid-19, it translates into one of the biggest threat facing any treating doctor in the world. There is a need to intellectualise understanding of outbreaks with valuable recommendations crucial to preventing or curtailing any future outbreak of the disease. For this, a meticulous data collection, compilation of line-lists and analysis of outbreak investigations are recommended to define the epidemiology of the epidemic, to guide quick and operative reactive campaigns. Population-based coverage surveys should be implemented to determine the susceptibility profile and to recognize spaces of low coverage to better prioritize and resourcefully use capitals in order to target the most vulnerable groups. There is also a desideratum to garner international attention and take steps to increase public awareness.

In DRC, we all need all your prayers!!!

\section{References:}

1. Norwegian Refugee Council. Congo Ebola outbreak compounds already dire humanitarian crisis [Internet]. New York: OCHA; 2018 [cited 2020 Jun 6]. Available from: https://reliefweb.int/report/democratic-republiccongo/congo-ebola-outbreak-compounds-already-dire-humanitarian-crisis

2. UN News. Conflict in new Ebola zone of DR Congo exacerbates complexity of response: WHO emergency response chief [Internet]. New York: UN; 2018 [cited 2020 Jun 6]. Available from: https://news.un.org/en/ story/2018/08/1016262

3. Philippe MT, Karume K. Assessing forest cover change and deforestation hot-spots in the north Kivu Province, DR-Congo using remote sensing and GIS. Am J Geogr Inf Syst. 2019; 8(2): 39-54.

4. UN News. Ebola-hit DRC faces 'perfect storm' as uptick in violence halts WHO operation [Internet]. New York: UN; 2018 [cited 2020 Jun 6]. Available from: https://news.un.org/en/story/2018/09/1020392

5. WHO. History of Ebola in Democratic Republic of the Congo [Internet]. Geneva: WHO [cited 2020 Jun 6]. Available from: http://www.who.int/ebola/historical-outbreaks-drc/en/

6. WHO. Ebola virus disease - Democratic Republic of the Congo [Internet]. Geneva: WHO; 2020 [cited 2020 Jun 6]. Available from: https://www.who.int/csr/don/05-March-2020-ebola-drc/en/

7. Branswell H. New Ebola case dashes hopes that the 2-year-old DRC outbreak was over [Internet]. Boston: STAT; 2020 [cited 2020 Jun 6]. Available from: https://www.statnews.com/2020/04/10/new-ebola-casedashes-hopes-drc-outbreak-over/

8. Centers for Disease Control and Prevention. Ebola virus disease distribution map: cases of Ebola virus disease in Africa since 1976 [Internet]. Atlanta: Centers for Disease Control and Prevention; 2019 [cited 2020 Jun 6]. Available from: https://www.cdc.gov/vhf/ebola/history/distribution-map.html

9. Parpia AS, Ndeffo-Mbah ML, Wenzel NS, Galvani AP. Effects of response to 2014-2015 Ebola outbreak on deaths from malaria, HIV/AIDS, and tuberculosis, West Africa. Emerg Infect Dis. 2016; 22(3): $433-441$. https://doi.org/10.3201/eid2203.150977

10. WHO. Coronavirus disease (COVID-19) pandemic [Internet]. Geneva: WHO [cited 2020 Jun 6]. Available from: https://www.who.int/emergencies/diseases/novel-coronavirus-2019

11. WHO. Coronavirus disease (COVID-19) Situation Report - 137. Data as received by WHO from national authorities by 10:00 CEST, 05 June 2020 [Internet]. Geneva: WHO; 2020 [cited 2020 Jun 6]. Available from: https://www.who.int/docs/default-source/sri-lanka-documents/20200605-covid-19-sitrep-137. pdf?sfvrsn=a13df572_2

12. WHO. New Ebola outbreak detected in northwest Democratic Republic of the Congo; WHO surge team supporting the response [Internet]. Geneva: WHO; 2020 [cited 2020 Jun 6]. Available from: 
https://www.who.int/news-room/detail/01-06-2020-new-ebola-outbreak-detected-in-northwestdemocratic-republic-of-the-congo-who-surge-team-supporting-the-response

13. WHO. Deaths from Democratic Republic of the Congo measles outbreak top 6000. WHO Regional Office for Africa [Internet]. Geneva: WHO; 2020 [cited 2020 Jun 6]. Available from: https://www.afro.who.int/news/ deaths-democratic-republic-congo-measles-outbreak-top-6000 